\title{
Współczesny model rosyjskiego federalizmu: dynamika zmian, przesłanki i konsekwencje
}

\section{Stosunki federacyjne w Rosji w świetle współczesnych teorii federalistycznych}

W latach 90. XX wieku federalizm pojawił się w rosyjskim systemie politycznym w postaci modelu federalizmu spajającego (holding-together federalism), przeciwstawianego modelowi federalizmu zbliżającego (coming-together federalism) ${ }^{1}$. Federalizacja Rosji odzwierciedlała próby zachowania integralności terytorialnej tego państwa w obliczu narastających tendencji decentralistycznych, wywołanych procesem rozpadu Związku Radzieckiego ${ }^{2}$. Decentralizacji funkcji władczych pomiędzy centrum i regionami, przyjęcie Umowy Federacyjnej, zawarcie całego szeregu umów o rozgraniczeniu kompetencji i zakresów działania, powołanie do życia Rady Federacji sprzyjały ograniczeniu poczynań rządu federalnego i zwiększyły liczbę veto players $\mathrm{w}$ systemie politycznym $^{3}$. Przyczyniło się to również do stworzenia wielu aren, na których rozgrywały się procesy organizacji i mobilizacji interesów grupowych ${ }^{4}$.

System polityczny Rosji był obarczony dziedzictwem silnie rozbudzonych tendencji decentralistycznych, które w warunkach zejścia Rosji ze ścieżki demokratyzacyjnej

1 A. Stepan, Toward a New Comparative Analysis of Democracy and Federalism: Demos Constraining and Demos Enabling Federations, Paper presented at the conference on Federalism, Democracy, and Public Policy Centro de Investigación y Docencia Económicas, Mexico City, Mexico June 14-15, 1999.

2 Idem, Federalism and Democracy: Beyond the U.S. Model, „Journal of Democracy” 1999, vol. 10, nr 4, s. 22-23.

3 George Tsebelis zdefiniował veto players jako zbiór tych aktorów zbiorowych i indywidualnych, których zgoda jest wymagana, aby osiągnąć zmianę ustawodawczego status quo lub szerzej - zmianę polityki. Por. G. Tsebelis, Veto Players: How Political Institutions Work, Princeton University Press, Princeton-New York 2011, s. 2.

4 C. Ross, R. Turovsky, Centralized but Fragmented: The Regional Dimension of „Russia's Party of Power”, „Demokratizatsiya” 2015, vol. 23, nr 2, s. 206. 
skutkowałyby wykształceniem się w niej w latach 90 . XX wieku zjawiska subnarodowego autorytaryzmu ${ }^{5}$. Zagadnienie dotyczące jego genezy i kształtowania się w Rosji stanowi fragment szerszego problemu, jakim jest instytucjonalizacja zjawiska autorytarnego federalizmu. Zdaniem większości teoretyków, federalizm nie może istnieć poza środowiskiem demokratycznym - autonomia i subsydiarność są bowiem niekompatybilne z podporządkowaniem i przymusem ${ }^{6}$.

Jednak, jeśli przyjąć perspektywę neo-jarłyku, w ramach którego podmioty składowe państwa federalnego walczą o swą suwerenność i negocjują jej zasady z rządem federalnym, można założyć, iż federalizm był obecny w Rosji w omawianym okresie w wymiarze procesualnym. William $\mathrm{H}$. Riker traktował bowiem federalizm jako nieustający proces negocjacji pomiędzy różnymi poziomami władzy w obrębie systemu federalnego. Dlatego też dostrzegal - z zastrzeżeniami - obecność federalizmu nawet w systemie politycznym Związku Radzieckiego, przyjmując jednocześnie, że w grę wchodzi szczególny model federalizmu?

Rozważania Rikera dotyczące federalizmu są szczególnie interesujące, zdaniem bowiem większości rosyjskich i zachodnich autorów system polityczny Rosji uległ w okresie rządów Władimira Putina defederalizacji. Riker skonstruował oś continuum federalizmu wyznaczaną przez dwa antynomiczne typy idealne - minimalny i maksymalny federalizmu. Typ minimalny federalizmu (luźny związek) charakteryzował się tym, że rząd centralny miał możliwość podejmowania suwerennej decyzji, w co najmniej jednym obszarze, bez konieczności uzyskiwania akceptacji podmiotów składowych. Typ maksymalny federalizmu odnosi się do sytuacji, w której rząd federalny może swobodnie podejmować wiążące decyzje, bez konieczności zabiegania o zgodę regionów we wszystkich obszarach działania poza jednym ${ }^{9}$.

Jednocześnie należy podkreślić, że w Rosji proces poszukiwania najbardziej optymalnego mechanizmu zarząazania regionami, np. w wymiarze polityki kadrowej, toczył się nieustannie z małymi przerwami od samego momentu implementacji rozwiązań federalistycznych $\mathrm{w}$ tamtejszym systemie politycznym ${ }^{10}$. W literaturze przedmiotu poświęconej zagadnieniu decentralizacji funkcji władczych w Rosji szczególne miejsce zajmuje model nadzoru Kongresu nad Prezydentem Stanów Zjednoczonych Ameryki

5 The Politics of Sub-National Authoritarianism in Russia, red. C. Ross, V. Gel'man, Routledge, Ashgate, Aldershot 2010

6 J. Kahn, Russia: Federalism, Democratization, Rule of Law, Oxford University Press, Oxford 2002, s. $48-49$.

7 W.E. Riker, The Development of American Federalism, Kluwer Academic Publisher, Boston 1987, s. 10.

8 Ibidem, s. 12.

9 C. Volden, The Federalism of William H. Riker Origin, Operation, and Significance, „Publius: The Journal of Federalism" 2004, vol. 34, nr 4, s. 101.

10 А. Перцев, С. Самохина, И. Синергиев, Региональные переменные. Чего хочет Москва от новых губернаторов, „Коммерсантъ Власть” 11.02.2017; С. Самохина, Кремль разработал критерии эффективности для губернаторов, Лента новостей (Москва) от 17.02.2017, 16:14, Коммерсантъ, http://www.kommersant.ru/doc/3223648, inf. z 18 II 2017. 
autorstwa Mathew McCubbinsa i Thomasa Schwartza. Obydwaj autorzy, podejmując problem relacji zleceniodawca-zleceniobiorca (principal-agent problem), w ramach której zleceniodawca, delegując część funkcji władczych zleceniobiorcy, oczekuje od niego skuteczności w realizacji powierzonych mu zadań. Aby osiągnąć ten cel, zleceniodawca ma do wyboru dwie strategie monitoringu swego zleceniobiorcy: „patrolu policyjnego" i „alarmu przeciwpożarowego”. Pierwszy z nich zakłada obecność działania zewnętrznego, odgórnego, cyklicznego sprawdzania poczynań zleceniobiorcy, np. przez wyspecjalizowane agencje. W przypadku „alarmu przeciwpożarowego” mamy do czynienia $\mathrm{z}$ monitoringiem wewnętrznym - zleceniobiorca poddawany jest kontroli przez podmioty niezwiązane ze zleceniodawcą. Do tego ostatniego docierają informacje o zachowaniu zleceniobiorcy niezależnie od tego, czy sobie tego życzy, czy nie, ze strony podmiotów, którym zleceniobiorca miał służyć. W praktyce model „patrolu policyjnego" polega na powoływaniu przez organy władzy państwowej dodatkowych agencji nadzorujących poczynania zleceniobiorcy, tj. innych urzędników państwowych i organów władzy państwowej. W przypadku „alarmu przeciwpożarowego” kontrola urzędników i agend państwowych odbywa się poza państwem, z wykorzystaniem mediów bądź też społeczeństwa obywatelskiego ${ }^{11}$.

Brian Taylor zwrócił uwagę na to, że każdy z tych modeli sprzyja wzrostowi efektywności działań państwa, ale to model „alarmu przeciwpożarowego” podnosi jakość rządzenia. W konsekwencji obydwa modele powinny być stosowane równolegle ${ }^{12}$.

Andreas Schedler przywołał natomiast bardzo rozbudowany katalog możliwych form funkcjonowania autorytarnego federalizmu, w ramach którego obóz władzy w zależności od wypracowanego modus operandi:

- występuje w charakterze arbitra pomiędzy zwaśnionymi grupami elit regionalnych (system arbitrażu);

- stosuje równolegle metody administracyjnego nadzoru i fizycznej przemocy (system represji);

- konstruuje rozbudowane struktury administracyjne, będące agendami rządu centralnego, mającego monitorować poczynania organów władzy szczebla regionalnego (model administracyjny);

- rezygnuje z tradycyjnych metod kontroli administracyjnej, np. ręcznego zarządzania, i deleguje organom władzy niższego szczebla znaczny zakres pełnomocnictw, w zamian oczekując efektów politycznych (spokój społeczny) i niepolitycznych (dobrobyt społeczeństwa, efektywność gospodarcza), jednocześnie dysponuje narzędziami

11 A. Starodubtsev, Decentralize but not Federalize: The Authoritarian Pattern of Regional PolicyReportfor ECPR General Conference 2013, 4-7 September, 2013, ECPR General Conference, https://ecpr. eu/.../239166c3-0dd8-456b-a58f-1e0f6de73ed2.pdf, inf. 9 VI 2018; B. Taylor, State Building in Putin's Russia: Policing and Coercion after Communism, Cambridge University Press, Cambridge 2011, s. 29-30.

12 Ibidem, s. 30. 
formalno-prawnymi, czyniącymi organy władzy niższego szczebla w pełni odpowiedzialnymi przed centrum (model zarządzania) ${ }^{13}$.

Przywołane modele funkcjonowania federalistycznego autorytaryzmu zdecydowanie wpisują się w model „patrolu policyjnego”. Model „alarmu przeciwpożarowego" wydaje się być niekompatybilny z reżimami autorytarnymi, ze względu na ograniczenie roli społeczeństwa obywatelskiego i wolności mediów w tego typu reżimach.

Celem pracy jest osadzenie rosyjskiego modelu federalizmu (przemian dokonujących się w układzie centrum-regiony) we współczesnej siatce teoretyczno-pojęciowej federalizmu. Szczególnie interesująca, zdaniem autora, jest próba odniesienia rosyjskiego modelu stosunków federacyjnych do osi typów idealnych federalizmu autorstwa W.H. Rikera i koncepcji modelu „patrolu policyjnego" i „alarmu przeciwpożarowego”.

Zmiany dokonujące się w obrębie rosyjskiego modelu federalistycznego mają, jeśli uwzględnić analizowane przez autora w tekście zagadnienia, istotny wpływ na charakter rosyjskiego systemu politycznego i jakość funkcjonowania rosyjskiej państwowości. Autor uwzględnił w tym rozdziale następujące zagadnienia: 1) ewolucję stosunków federacyjnych w Rosji po roku 1999; 2) instytucjonalizację systemu mechanizmu monitoringu działań organów władzy państwowej szczebla regionalnego; 3) ewolucję kształtowania się nowego formatu relacji Kreml-elity regionalne, utrzymanego w duchu modelu neo-jarłyku; 4) przesłanki zmian w obrębie systemu stosunków federacyjnych i ich konsekwencje.

\section{Dynamika zmian w obrębie systemu stosunków centrum-regiony w Rosji w latach 2000-2016}

W Rosji w latach 2000-2016 miała miejsce daleko idąca ewolucja idei i praktyki federalizmu, co wiązało się z przemianami w systemie stosunków centrum-regiony, dokonującymi się w omawianym okresie. W tym czasie stosunki federacyjne uległy daleko idącej centralizacji w stosunku do lat 1990-1999. Okres ten charakteryzował się natomiast gwałtownym i niekontrolowanym procesem decentralizacji, a w jego ramach można wyodrębnić dwa etapy:

1) „parady suwerenności”, przypadający na lata 1990-1993;

2) asymetrycznego federalizmu - w latach 1993-1999.

Pierwszy z nich charakteryzował się „paradą suwerenności”, tj. serią deklaracji suwerenności ogłoszonych przez podmioty składowe (republiki) Rosyjskiej Federacyjnej Socjalistycznej Republiki Radzieckiej, będących pokłosiem walki pomiędzy Borysem Jelcynem a Michaiłem Gorbaczowem i odpowiedzią na ustawę przyjętą w kwietniu $1990 \mathrm{r}$. w Związku Radzieckim O rozgraniczeniu pełnomocnictw pomiędzy Związkiem Socjalistycznych Republik Radzieckich i podmiotami Federacji. Zrównywała ona status republik autonomicznych i związkowych ZSRR. W obawie przed utratą ogromnej części terytorium i potencjału gospodarczego Rosji Borys Jelcyn, przebywając w Ufie, 6 sierpnia

13 A. Schedler, The New Institutionalism in the Study of Authoritarian Regimes, „Totalitarismus und Demokratie" 2009, nr 6, s. 336. 
1990 r. zaproponował: „Bierzcie tyle suwerenności, ile zdołacie przełknąć”, ale w domyśle: pozostańcie w Federacji Rosyjskiej ${ }^{14} .31$ marca 1992 r. podpisano Umowę Federacyjną, dokonującą rozgraniczenia zakresów działania i pełnomocnictwa, która miała powstrzymać proces rozpadu Rosji ${ }^{15}$. Do czasu przyjęcia w grudniu roku 1993 Konstytucji Federacji Rosyjskiej wytyczała ona zasady relacji centrum-regiony. W okresie „parady suwerenności” wiele regionów, głównie republik narodowościowych, w sposób jednostronny określiło, jakim zakresem pełnomocnictw będzie dysponowało samodzielnie. Kreml zaniepokojony wizją rozpadu struktury terytorialnej Rosji, pogrążony w rozwiązywaniu problemów społeczno-politycznych, a później także zaangażowany w konflikt ze Zjazdem Deputowanych Ludowych, zaakceptował rosnące ambicje elit republikańskich, w zamian za lojalność i obietnicę pozostania w granicach Rosji. Jedynym regionem, który posunął się dalej, była Czeczenia, która dokonała aktu secesji.

W okresie 1993-1999 stosunki federacyjne miały wytyczać normy konstytucji, sam zaś federalizm miał mieć charakter konstytucyjny, a nie traktatowy - co było zgodne z duchem Umowy Federacyjnej. Regiony skorzystały skwapliwie z prawa do kształtowania w sposób samodzielny reżimów konstytucyjnych i politycznych. W drugiej połowie lat 90. XX wieku przed regionami otworzyła się możliwość organizowania powszechnych wyborów gubernatorów; prezydenci republik narodowościowych wywalczyli to prawo już wcześniej. Elity polityczne ustanowiły w regionach dość złożone spektrum reżimów politycznych - od w pełni demokratycznych do skonsolidowanych autorytaryzmów, z silnie zarysowanym wpływem komponentu etnicznego. Dywersyfikacja regionalnych reżimów politycznych, a w szczególności pojawienie się zjawiska subnarodowego autorytaryzmu, były z jednej strony przejawem zdolności elit regionalnych do korumpowania federalnych urzędników w regionach, a zarazem słabości centrum w egzekwowaniu norm ustawodawstwa federalnego, w tym zapisów konstytucji. Z drugiej zaś strony stanowiły świadectwo istnienia asymetrii w relacjach pomiędzy centrum a regionami. Podmioty składowe Rosji różniły się pomiędzy sobą w wymiarze strukturalnym, co miało wpływ na ich relacje z centrum i charakter rosyjskiego federalizmu. Najsilniejsze z regionów - świadome swego znaczenia politycznego, wynikającego z potencjału ludnościowego i ekonomicznego - zdołały zawrzeć niezwykle korzystne dwustronne umowy z centrum o rozgraniczeniu zakresów działania i pełnomocnictw. Relacje centrum-regiony były w omawianym okresie oparte w dużym stopniu na bezpośrednich relacjach pomiędzy Borysem Jelcynem a najbardziej wpływowymi przedstawicielami elit regionalnych. Model relacji centrum-regiony był spersonifikowany i nosił cechy neo-jarłyku. Rosyjski federalizm ulegał procesowi „feu-

14 Н. Корченкова, Вся власть субъектам. Как в России менялись федеративные отнотения в спеицильном проекте „Ђ”,„Коммерсантъ”, 31 III 2018, Коммерсантъ, https://www.kommersant. ru/doc/3585452, inf. 11 X 2018; Борис Ельцин: „Берите столько суверинетета, сколько сможете проглотить", 6 VIII 2015, Президентский Центр Б.Н. Ельцина, https://yeltsin.ru/news/boriselcin-berite-stolko-suverineteta-skolko-smozhete-proglotit/, inf. 16 VI 2018.

15 Федеративный договор (Москва, 31 марта 1992 г.), НПП „Гарант-Сервис”, http://constitution. garant.ru/act/federative/170280/, inf. 16 VI 2018; Борис Ельцин..., ор. cit. 
dalizacji”'16. Kreml, w zamian za autonomię polityczną i gospodarczą oferowaną części regionów, otrzymywał z ich strony lojalność. Poparcie regionalnych liderów uchroniło w roku 1996 Jelcyna (i elitę biznesowo-polityczną z nim związaną) od przegranej w wyborach prezydenckich i utraty kontroli nad Rosją. Mimo podejmowanych przez Kreml prób ograniczenia samowoli regionów i podporządkowania ich centrum federalnemu, a także istnienia przed rokiem 1999 formalno-prawnych instrumentów wymuszania posłuszeństwa ze strony regionów, w postaci ustawy regulującej tryb interwencji federalnej, elity rządzące tych ostatnich skutecznie opierały się wszelkim próbom subordynacji. Zaangażowanie armii w celu zduszenia czeczeńskiej rebelii nie przyniosło skutku - republika pozostała de facto niepodległa, Kreml nie był zdolny do usunięcia z urzędu gubernatora Kraju Nadmorskiego Jewgienija Nazdratenki, utrudniającego zbliżenie w relacjach rosyjsko-chińskich ${ }^{17}$.

Wraz z wyborem Władimira Putina na stanowisko prezydenta Rosji w marcu 2000 r. rozpoczął się okres centralizacji stosunków federacyjnych i przebudowy dotychczasowych zasad relacji centrum-regiony, niekorzystnych dla centrum. Początek tego procesu był poprzedzony frondą regionów. W przededniu wyborów do Dumy Państwowej Federacji Rosyjskiej w roku 1999 szefowie szeregu znaczących regionów, na czele z Moskwą, Sankt-Petersburgiem i Tatarstanem, sformowali koalicję partyjną pod nazwą „Ojczyzna - Cała Rosja”, której celem było zwycięstwo w wyborach do Dumy Państwowej w roku 1999, a następnie przejęcie kontroli nad urzędem prezydenckim, po mającym wkrótce nastąpić jego opróżnieniu przez schorowanego i zniedołężniałego Jelcyna. Plany te nie zostały zrealizowane. W wyborach parlamentarnych bardzo dobry wynik osiągnęła kremlowska „partia władzy”, a pełniący obowiązki prezydenta Władimir Putin wygrał wybory prezydenckie już w pierwszej turze. Rozpoczął się proces odbudowy jednolitej konstytucyjno-prawnej przestrzeni Rosji, co odbywało się pod hasłem „dyktatury prawa”.

W ramach recentralizacji stosunków federacyjnych nastąpiło ograniczenie wpływu regionów na proces decyzyjny na szczeblu federalnym (zmiana zasad wyboru członków Rady Federacji) i regionalnym (wyeliminowanie powszechnych wyborów najwyższych osób urzędowych w podmiotach składowych Federacji Rosyjskiej). Wzmocniono zakres kontroli nad regionami w ramach programu budowy „pionowo zintegrowanej struktury władzy wykonawczej” przez ustanowienie instytucji pełnomocnego przedstawiciela prezydenta FR w okręgu federalnym obejmującym kilka-kilkanaście regionów, „penetrację" regionalnych systemów politycznych przez federalną „partię władzy”, wprowadzenie zakazu funkcjonowania partii regionalnych. Nastąpiło przeniesienie części zasobów i kompetencji regionów na rzecz centrum federalnego. Rozwiązano umowy dwustronne centrum-regiony o rozgraniczeniu zakresów działa-

16 I. Busygina, Russian Federalism, [w:] Russia Strategy, Policy and Administration, red. I. Studin, Palgrave Macmillan, UK, Basingstoke 2018, s. 60.

17 Russia's Far East, red. J. Thornton, C.E. Ziegler, National Bureau of Asian Research, Seattle-London 2002, s. 46. 
nia i kompetencji - zastąpił je zbiór ustaw federalnych precyzujących zapisy konstytucyjne mówiące o kompetencjach wspólnych federacji i podmiotów. W wyniku zmian w sferze „federalizmu budżetowego" struktury władzy podmiotów federacji utraciły samodzielność w odniesieniu do możliwości wyboru celów rozwoju i sposobów ich osiągania, a ich działalność była ściśle reglamentowana na poziomie federalnym - podmioty federacji stały się agendami rządu federalnego.

Centrum federalne doprowadziło do skrajnej centralizacji finansowej. Znacznie skurczył się udział budżetów podmiotów w skonsolidowanym budżecie FR, w porównaniu z latami 90. XX wieku - w roku 1998 kształtował się on na poziomie $54 \%{ }^{18}$. Już w roku 2005 regiony zachowywały tylko $45 \%$ środków na potrzeby wykonania pełnomocnictw własnych i realizację zadań o znaczeniu lokalnym, a w roku 2010 udział ten skurczył się do poziomu 37\%. W roku 2015 udział budżetów regionalnych w skonsolidowanym budżecie Rosji zmniejszył się jeszcze bardziej - do $30 \%^{19}$. W okresie $2005-2010$ udział docelowych transferów między budżetami federalnym i regionalnymi wzrósł z poziomu $24 \%$ w roku 2005 do $63 \%$ w roku 2010. W roku 2017, według słów wicepremiera Dmitrija Kozaka, tylko 12 regionów było w stanie podzielić się swoimi dochodami z budżetem federalnym, reszta musiała szukać pomocy w centrum w celu wywiązania się ze swych zobowiązańn ${ }^{20}$. Trudno w takich warunkach mówić o samodzielności większości rosyjskich regionów, niezależnie od trybu powoływania ich szefów.

Od roku 2000 konsekwentnie rosła liczba urzędników państwowych i municypalnych. W ciągu 16 lat ich liczba się podwoiła. Z punktu widzenia dyskusji nad ewolucją stosunków centrum-regiony i poszukiwania przez Kreml skutecznego mechanizmu monitorowania działań organów władzy szczebla regionalnego i municypalnego kluczowe znaczenie miały następujące fakty. Liczba urzędników federalnych pracujących w regionach niemal podwoiła się w latach 2000-2009 (z 482 do 830 tysięcy) - od roku 2010 odnotowuje się stopniową, lecz wyraźną redukcję zatrudnienia, którą wiązano ze skutkami kryzysu finansowego w Rosji. Liczba urzędników federalnych pracujących w regionach zdecydowanie górowała nad liczbą urzędników państwowych szczebla regionalnego - w roku 2000 kształtowała się ona w proporcjach 482 do 192 tysięcy, w roku 2009 natomiast na 830 tysięcy urzędników federalnych przypadało 283 tysięcy osób zatrudnionych w regionalnych organach władzy państwowej ${ }^{21}$.

18 А.Я. Запорожан, Проблемы и тенденции развития межбюджетных отношений в России, „Управленческое Консультирование” 2015, nr 4, s. 72.

19 И. Стародубровская, В. Глазычев, Федерализм истинньй имнимый, Статья является фрагментом доклада „Стратегия-2020: Новая модель роста - новая социальная политика”, подготовленного группой российских экспертов, „Московские новости”, 14IX 2011, Московские новости, https:// www.hse.ru/data/2013/10/30/1283340742/\%D0\%A1\%D1\%82\%D1\%80\%D0\%B0\%D1\%82\%D0\%B5\% D0\%B3\%D0\%B8\%D1\%8F-2020_\%D0\%9A\%D0\%BD\%D0\%B8\%D0\%B3\%D0\%B0\%201.pdf, inf. $11 \mathrm{X}$ 2018; Н. Корченкова, op. cit.

20 Н. Корченкова, op. cit.

21 Численность работников государственных органов и органов местного самоуправления Российской Федерации, Обновлено 06.04.2018, Федеральная служба государственной 
Od roku 2014 Federalna Służba Statystyczna zaczęła uwzględniać w swych szacunkach dotyczących liczby federalnych i regionalnych urzędników państwowych liczebność terytorialnych organów Ministerstwa Spraw Wewnętrznych Rosji - miało to znaczący wpływ na zrozumienie skali obecności urzędników federalnych na poziomie regionalnym, jeśli bowiem ich liczba w roku 2013 była szacowana na 744 tysiące osób, to w roku 2014, z uwzględnieniem pracowników MSW, wzrosła do 1404700 osób ${ }^{22}$. Nawet biorąc pod uwagę fakt, że w roku $2016 \mathrm{w}$ strukturach municypalnych pracowało 477 tysięcy osób, a na szczeblu regionalnym 259 tysięcy, to i tak „armia” urzędników federalnych nadzorujących ich działania była niemal dwukrotnie większa i wynosiła 1360700 osób $^{23}$.

Po roku $2000 \mathrm{w}$ regionach pojawiły się nowe struktury federalne, np. w postaci instytucji pełnomocnego przedstawiciela Prezydenta FR w okręgu federalnym, którym powierzono m.in. zadania nadzorowania i wspierania procesu przywracania zgodności ustawodawstwa regionalnego $\mathrm{z}$ federalnym i koordynowania rotacji kadr struktur siłowych w regionach. Biorąc pod uwagę charakter tego drugiego zadania, zrozumiały staje się fakt, że pięciu z siedmiu pierwszych pełnomocnych przedstawicieli miało doświadczenie $\mathrm{w}$ pracy $\mathrm{w}$ strukturach siłowych: armii, ministerstwie spraw wewnętrznych Związku Radzieckiego czy KGB. Powiązania ze strukturami siłowymi miały pozostać cechą szczególną pełnomocnych przedstawicieli prezydenckich w okręgach federalnych, które stały się mniej widoczne w okresie prezydentury Dmitrija Miedwiediewa, ale już w okresie 2014-2015 trzech nowych pełnomocnych przedstawicieli prezydenckich nosiło mundury ${ }^{24}$.

\section{Zmiana zasad funkcjonowania systemu stosunków centrum-regiony, a jakość zarządzania państwem}

Model „patrolu policyjnego” w stosunkach centrum-regiony zaczął być w Rosji implementowany dosłownie, w szczególności po roku 2014. Działania antykorupcyjne struktur siłowych zdominowały regionalne systemy polityczne, a ludzie wywodzący się z nich zaczęli zajmować stanowiska szefów regionów. Implementacja tego modelu monitoringu działań organów władzy państwowej szczebla regionalnego zaczęła przybierać formy wymuszania politycznego posłuszeństwa, zastraszania elit regionalnych, przejmowania aktywów gospodarczych. Jednocześnie nie pojawił się spójny i zinstytucjonalizowany w czasie mechanizm oceny pracy szefów regionów, choć dochodziło

статистики, $h t t p: / / w w w . g k s . r u / w p s / w c m / c o n n e c t / r o s s t a t+m a i n / r o s s t a t / r u / s t a t i s t i c s /$ state/\#, inf. 16 VI 2018.

22 Ibidem; И. Голубицкая, За 15 тет число чиновников в России выросло вдвое, „Myslo.ru” 16.01.2017, Myslo.ru, https://myslo.ru/news/tula/2017-01-16-za-15-let-chislo-chinovnikov-vRossii-viroslo-vdvoe, inf. 16 VI 2018.

23 Численность работников государственных органов..., ор. сіt.

24 Н. Петров, К. Рогов, Исполнительная власть и силовые корпораиии, [w:] Политическое развитие России. 2014-2016: Институты и практики авторитарной консолидации, red. А.В. Кынев, А.Г. Качкаева, Э.Л. Панеях, Фонд Либеральная миссия, Москва 2016, s. 139. 
do wielu prób w tym zakresie, podejmowanych także przez organizacje analityczne, np. Fundację Petersburską Polityka, która publikowała cykliczne rankingi stabilności regionów i czasu przetrwania ich szefów.

Rosyjskie państwo zdobyło potencjał do oddziaływania na regiony, ale nie zwiększyło to poziomu jakości rządzenia ${ }^{25}$. Kreml nie był zdolny osiągać zakładanych celów w zakresie ich długofalowego rozwoju społeczno-gospodarczego, nawet jeśli w grę wchodził rozwój makroregionów o szczególnym znaczeniu geopolitycznym (np. Daleki Wschód) ${ }^{26}$. Brian Taylor zwrócił uwagę na to, że: „Pod rządami Putina resorty siłowe zwiększyły swój potencjał oddziaływania w sytuacjach nadzwyczajnych, takich jak stosowanie represji wobec gospodarczych i politycznych rywali członków obozu władzy. Jednak nie polepszyły swoich osiągnięć w zakresie swych rutynowych zadań; zwalczania przestępczości i terroryzmu czy ochrony własności prywatnej”27.

Relatywnie mała liczba osób „w pagonach” pełniących funkcje szefów regionów po roku 1999 dowodzi uświadomienia sobie przez Kreml faktu, że struktury siłowe sprawdzają się w roli czynnika dyscyplinującego elity regionalne, nie zaś administratora procesów politycznych i społeczno-gospodarczych.

Kreml skutecznie odwrócił wektor rozwoju stosunków federacyjnych ukształtowany w latach 90. XX wieku. Miejsce decentralizacji funkcji władczych i autonomii podmiotów składowych Federacji Rosyjskiej, a także tendencji do indywidualnego (niezinstytucjonalizowanego) kształtowania relacji centrum-regiony zajęła centralizacja zasobów finansowych, wyraźne rozgraniczenie pełnomocnictw i doprowadzenie ustawodawstwa regionalnego do zgodności z federalnym ${ }^{28}$. Autorzy Strategii 2020, powstałej z udziałem naukowców z Rosyjskiej Akademii Gospodarki Narodowej i Służby Państwowej przy Prezydencie Federacji Rosyjskiej oraz Wyższej Szkoły Gospodarczej w Moskwie, deklarujący troskę o konieczność modernizacji rosyjskiego państwa, krytycznie oceniali osiągnięcia epoki Putina w dziele stosunków federacyjnych.

Jeśli nawet przyjąć założenie, że tego typu polityka miała zapewnić harmonijną współpracę wszystkich poziomów władzy państwowej z myślą o modernizacji państwa, to osiągnięte efekty wywoływały wiele wątpliwości i to nie tylko z powodu ich niekompatybilności z duchem federalizmu. Ukształtowany pod rządami Putina model stosunków federacyjnych, ze względu na daleko idącą centralizację i dążenie za wszelką cenę do zachowania spokoju społecznego w regionach, miał - zdaniem autorów Stra-

25 K. Stoner-Weiss, Resisting the State: Reform and Retrenchment in Post-Soviet Russia, Cambridge University Press, Cambridge 2006, s. 147; A. Starodubtsev, Bureaucratic Strength and Presidential Inattention: Disempowering Territorial Development Instruments in Russia, „Russian Analytical Digest” 18.04. 2017, nr 201, s. 10-12, Russian Analytical Digest, http://www.css.ethz.ch/content/ dam/ethz/special-interest/gess/cis/center-for-securities-studies/pdfs/RAD201.pdf, inf. 08 IX 2018.

26 Н. Зубаревич, „Бремя регионов”: что изменилось за десять лет?, „Контрапункт” 2016, nr 6, s. 4; Idem, Геополитические приоритеты в региональной политике России: возможности и риски, „Контрапункт” 2015, nr 1, s. 5-7.

27 B. Taylor, op. cit., s. 35.

28 И. Стародубровская, В. Глазычев, op. cit. 
tegii 2020 - stawiać pod dużym znakiem zapytania możliwość modernizacji państwa ${ }^{29}$. Zwracano m.in. uwagę na to, że:

1) organy władzy podmiotów federacji utraciły samodzielność w odniesieniu do możliwości wyboru celów rozwoju i środków ich osiągania, a ich działalność była ściśle reglamentowana na poziomie federalnym - podmioty federacji stały się agendami rządu federalnego;

2) centrum federalne doprowadziło do skrajnej centralizacji finansów państwa, znacznie skurczył się udział podmiotów w skonsolidowanym budżecie FR;

3) jeszcze bardziej - w porównaniu z okresem rządów Borysa Jelcyna - spadła transparentność rozdziału transferów między budżetami; na zasadzie naczyń połączonych wzrosło znaczenie subiektywnych czynników decydujących o rozdziale środków budżetowych - „asymetryczny federalizm” jawnie manifestujący swą obecność w poprzedniej dekadzie przestał się z nią afiszować;

4) naruszona została przez centrum federalna zasada konstytucyjnego rozgraniczenia pełnomocnictw; centrum wkracza w kompetencje regionów, realizując istotne dla swego publicznego wizerunku i społecznej legitymacji reżimu tzw. projekty narodowe, które powinny pozostawać w sferze kompetencji regionów i organów samorządu terytorialnego $0^{30}$.

\section{Procesualny wymiar przemian w obrębie rosyjskiego modelu federalistycznego}

Po roku 2000 elity regionalne, a w szczególności szefowie regionów, zostały postawione w obliczu zdecydowanych działań ze strony centrum federalnego, których celem było ograniczenie możliwości wpływu regionów na proces decyzyjny na szczeblu federalnym. Jednocześnie podjęto decyzje, które miały ograniczyć autonomię elit regionalnych - skupić ich swobodę działania w obrębie regionalnych systemów politycznych. Elity rządzące w regionach były pozbawiane zasobów, które dotychczas pozwalały znacznej części z nich prowadzić negocjacje z centrum federalnym na zasadach równowagi sił - tak że żadna ze strony nie była z założenia i trwale uprzywilejowana. Regionom odebrano kontrolę nad federalnymi agencjami w podmiotach. Szczególne znaczenie miała utrata wpływu na proces nominacji szefów resortów siłowych na poziomie regionalnym, pozbawiono je prawa weta w postępowaniu dotyczącym przyznawania licencji na eksploatację złóż surowców naturalnych, a w końcu wyeliminowano ich wybory powszechne - wyczerpało się tym samym źródło zasobu wyborczego i źródło społecznej legitymacji do rządzenia ${ }^{31}$.

Od roku 2000 daje o sobie znać istotna zmiana w modelu „feudalnych” relacji w układzie Kreml-elity regionalne. Te ostatnie ze względu na kurczące się zasoby oddziaływania przestawały być partnerem w procesie negocjacji. W latach 2000-2008 ule-

\footnotetext{
29 Ibidem.

30 Ibidem.

31 B. Taylor, op. cit., s. 134-135.
} 
gały podporządkowaniu i stawały się stroną w układzie zleceniodawca-zleceniobiorca. Proces negocjacji w dalszym ciągu jednak się toczył - przynajmniej do pierwszej połowy trzeciej prezydentury Putina. Część regionów dysponowała w nim większymi możliwościami od innych. Zgoła odmienny był bowiem np. status regionów donatorów budżetowych niż biorców. Centralizacja stosunków federacyjnych nie wyeliminowała strukturalnych różnic istniejących pomiędzy regionami, odnoszących się do ich wielkości, liczby ludności i struktury narodowościowej, bogactw naturalnych, warunków klimatycznych czy w końcu położenia geopolitycznego ${ }^{32}$. Reżimy polityczne rosyjskich regionów również były silnie zróżnicowane i pozycjonowane, np. z wykorzystaniem czterech osi: autonomia $v s$ podporządkowanie centrum; demokracja $v s$ autorytaryzm; monocentryzm $v s$ policentryzm; konsolidacja $v s$ rywalizacja ${ }^{33}$. Różny był także potencjał oddziaływania szefów regionów na centrum. Miało to przede wszystkim związek ze statusem regionu ${ }^{34}$.

Elity rządzące w regionach wciąż zachowywały jednak sporo autonomii wewnętrznej. Przede wszystkim Kreml nie miał możliwości, by bezpośrednio zarządzać regionami, np. kontrolować poczynania elit „drugiego rzędu” ${ }^{35}$. Pozostawiał szefom regionów znaczny zakres swobody działania, a nawet dopuszczał podporządkowanie im jednostek samorządu terytorialnego. Prezydenci republik narodowościowych i gubernatorzy dokonywali również „prywatyzacji partii władzy”, rozszerzając w ten sposób zakres swojej kontroli nad regionalnymi zgromadzeniami ustawodawczymi ${ }^{36}$. Stawali się beneficjentami wysiłków Kremla na rzecz budowy dominującej „partii władzy” - co z pewnością nie było zgodne z oczekiwaniami obozu władzy. W zgodnej opinii politologów rosyjskich badających tendencje społeczno-polityczne na rosyjskiej prowincji w okresie pierwszej i drugiej kadencji prezydenckiej Putina, centrum ograniczało swe zainteresowanie regionami do okresów wyborczych lub przypadków gwałtownych protestów społecznych bądź kryzysów związanych z bezpieczeństwem narodowym, elity zaś regionalne „Z wirtuozerią przekonują centrum, że realizują jego polecenia, w rzeczywistości nie robiąc nic, z tego, czego się od nich oczekuje"37.

32 N. Zubarevich, Four Russias: the New Political Reality, „Open Democracy” 01.02.2016, Open Democracy, https://www.opendemocracy.net/od-russia/natalia-zubarevich/four-russias-newpolitical-reality, inf. 06 IV 2017.

33 R. Turovsky, The Liberal and the Authoritarian: How Different Are Russian Regions?, [w:] The Politics..., s. 20.

34 Por. Рейтинг влияния глав субъектов Российской Федерации в ноябре 2016 г., 06.12.2016, Агентство политических и экономических коммуникаций, http://www.apecom.ru/ articles/?ELEMENT_ID=3262, inf. 6 IV 2017.

35 А.Е. Чирикова, Путинские реформы и позиционирование региональных элит в России, „Мир России. Социология. Этнология" 2006, nr 15 (1), s. 7; por. R. Turovsky, The Liberal and the Authoritarian..., s. 33.

36 А.Е. Чирикова, оp. cit., s. 8.

37 Eadem, Институт социологии Российской академии наук, Международный фондсоциальноэкономических и политологических исследований, http://www.gorby.ru/userfiles/chirikova(1). pdf, inf. z 9 VIII 2018. 
Z badań prowadzonych przez Ałłę Czirikową w roku 2006 wynikało, że znaczna część elit regionalnych zaczęła w końcu postrzegać feudalizację relacji centrum-regiony, nawet przyjmując fakt podporządkowania i wtłoczenia ich $\mathrm{w}$ wiele pionowo zintegrowanych struktur: wykonawczych, partyjnych, siłowych, jako proces korzystny. Nauczono się na poziomie regionalnym adaptować do nowych realiów. Korzystny był przede wszystkim napływ dodatkowych środków finansowych do podmiotów, np. na realizację projektów narodowych. Część szefów regionów afirmowała centralizację stosunków federacyjnych ze względu na rosnące poczucie stabilności i bezpieczeństwa, szczególnie mocno akcentowane to było przez elity republik kaukaskich ${ }^{38}$. Niewątpliwie w porównaniu z okresem 2000-2003, kiedy Czirikowa podjęła pierwsze badanie stosunku elit regionalnych do centralizacji modelu zarządzania państwem, ich krytyczne podejście do polityki Kremla uległo przewartościowaniu - znaczącemu złagodzeniu ${ }^{39}$.

Dostrzegalne były symptomy mutualizmu w relacjach centrum-regiony. Z jednej strony Kreml cenił sobie zdolności do mobilizacji zasobów administracyjnych szefów regionów, których znaczenie z punktu widzenia sukcesów wyborczych Jednej Rosji było istotne. $\mathrm{Z}$ drugiej zaś strony niektóre $\mathrm{z}$ regionów otrzymywały wsparcie $\mathrm{w}$ konflikcie $\mathrm{z}$ ambitnymi oligarchami, starającymi się przejąć w nich kontrolę. Można było wręcz odnieść wrażenie, że Kreml kupował lojalność regionów, a stosując wobec nich represje, demonstrował jedynie swą słabość ${ }^{40}$. Lojalność wobec Kremla stała się kluczowym elementem nowego kontraktu w układzie centrum-regiony ${ }^{41}$. Członkostwo w Jednej Rosji było z jednej strony ważną formą zademonstrowania lojalności wobec Kremla, z drugiej zaś dawało możliwości odzyskania utraconego wpływu na działalność Dumy Państwowej. Szefowie regionów ponosili jednak również odpowiedzialność za wyniki „partii władzy”.

W roku 2004 Kreml zdecydował, że nie oczekuje już, by szefowie regionów cieszyli się społeczną legitymacją ${ }^{42}$. Decyzja o zniesieniu wyborów szefów regionów była formalno-prawnym i zarazem symbolicznym kresem istotnej epoki w relacjach centrumregiony. Poprzedzona została wieloletnimi przygotowaniami, a elity regionalne ustąpiły woli Kremla pod wpływem kombinacji czynników strukturalnych i procesualnych.

W płaszczyźnie społecznej percepcji idei i zasad funkcjonowania federalizmu odnotowywano wysoki poziom niewiedzy. Poparcie dla decentralizacji funkcji władczych, a przede wszystkim odbudowy federalizmu budżetowego (zwiększenie autonomii podatkowej regionów) nie było symetryczne. Federalizm cieszył się popularnością

38 Eadem, Вертикаль власти в оценках региональных элит: динамика перемен, „Полис. Политические исследования" 2008, nr 6, s. 106.

39 Ibidem, s. 101-103.

40 И. Маркес, Е.Ю. Назруллаева, А.А. Яковлев, Деньги вместо роста: межбюджетные трансферты и электоральная поддержка в России, 2001-2008, Изд. дом Высшей школы экономики, Москва 2013.

41 Боос не останется губернатором Калининградской области, Rusbase, https://rb.ru/article/ boos-ne-ostanetsya-gubernatorom-kaliningradskoy-oblasti/6510297.html, inf. 6 VI 2018.

42 А.Е. Чирикова, op. cit., s. 9. 
w regionach - donorach, takich jak Kraj Permski czy Tatarstan, w których dodatkowo ukształtowało się silne poczucie tożsamości - odpowiednio regionalnej i narodowej. Jednocześnie idea wyborów powszechnych szefów regionów, a także deputowanych Rady Federacji cieszyła się niesłabnącą społeczną popularnością ${ }^{43}$.

W toku badań socjologicznych realizowanych w latach 2010-2012 zarówno z udziałem mieszkańców wybranych regionów Rosji, jak i ich elit politycznych ustalono, że „brakuje wyraźnie dominującego sentymentu w stosunku do autonomii regionalnej, nie dominuje afirmacja koncepcji federalizacji, decentralizacji czy też regionalizacji. Na dzień dzisiejszy nie istnieje zapotrzebowanie ani na polityczną, ani administracyjną autonomię podmiotów Federacji tak na poziomie obywatelskim, jak i elit regionalnych" 44 .

Część rosyjskich politologów odnotowujących pasywność zarówno szefów regionów, jak i szerzej elit regionalnych w obliczu decyzji o zniesieniu wyborów powszechnych, zwracało uwagę, że ani elity, ani lokalne społeczności nie uznawały politycznej autonomii za wartość, o którą warto walczyć. „Elity regionalne w swym potencjalnym konflikcie z centrum federalnym nie miały na kim się oprzeć, ponieważ centralizacyjny dyskurs Putina cieszył się popularnością wśród wyborców w skali całego kraju, z wyjątkiem kilku republik narodowościowych, których liderom zagwarantowano reelekcję, pod warunkiem akceptacji prezydenckiej inicjatywy"45.

Elity polityczne wycofały się z konfrontacji z Kremlem, m.in. pod wpływem oddziaływania czynników ideowych. I tak, Gulnaz Szarafutdinowa dowodziła, że elity w regionach zdały sobie sprawę, że epoka decentralizacji zakończyła się bezpowrotnie. Rosjan zaprzątała kwestia centralizacji państwa, odbudowy jego potencjału i statusu międzynarodowego. Rosja zyskała nowego lidera i środki finansowe na realizację jego planów modernizacji państwa ${ }^{46}$.

Wielu z liderów regionalnych zaczęło upatrywać w zmianach szansy na reelekcję, którą dawały nowe rozwiązania ustawodawcze. Najdłużej opierali się ci spośród nich, którzy dysponowali najlepiej rozwiniętymi strukturami wpływów w regionach, kontrolowali najwięcej zasobów i nie musieli spoglądać w stronę Kremla z nadzieją, że ten wesprze ich w walce o reelekcję $e^{47}$. Do maja 2006 r. procedurę mianowania zastosowano

43 М.В. Ноженко, А.В. Стародубцев, Одна научная загадка, или Почему губернаторы согласились с президентом, [w:] Федерализм и российские регионы: сборник статей, ИНИОН РАН, Москва 2006; К новой модели российского федерализма: взгляд из регионов. Доклады проекта - 2012, Горбачев-фонд, Москва 2012, s. 7-9.

44 Ibidem, s. 7-9.

45 А. Стародубцев, Бесполезное достижение? Губернаторские выборы в контексте проблем регионального развития, „Неприкосновенный запас” 2012, nr 4 (84), Горький Медиа, http:// magazines.russ.ru/nz/2012/4/s8.html, inf. 14 VI 2018.

46 G. Sharafutdinova, Gestalt Switch in Russian Federalism: The Decline in Regional Power under Putin, „Comparative Politics" 2009, vol. 45, nr 3, s. 358.

47 O.J. Reuter, The Politics of Cooptation. United Russia and Russia's Governors, s. 4, American Councils for International Education, http://researchfellowships.americancouncils.org/sites/ researchfellowships.americancouncils.org/files/Reuter_final_report.pdf, inf. 4 IV 2017. 
w 46 regionach 47 razy - w obwodzie tiumeńskim gubernator był powoływany dwukrotnie. W 34 przypadkach gubernatorem pozostała ta sama osoba. Szefowie regionów w początkowym okresie obowiązywania nowych zasad powoływania najwyższych osób urzędowych w regionach masowo składali swe pełnomocnictwa, aby uzyskać od prezydenta wotum zaufania i zapewnić sobie formalną nominację na stanowisko. Uczyniło tak do połowy 2006 roku 25 z nich - wszyscy oni zyskali poparcie Putina ${ }^{48}$. Kreml nie tylko, zgodnie z nieformalną umową, zagwarantował przedłużenie pełnomocnictw gubernatorów, których kadencja kończyła się w roku 2006, ale również zniósł w ustawie o systemie organizacji władz państwowych w regionach zasadę kadencyjności szefów władz wykonawczych.

Istniały w tym zakresie również inne teorie, które w pełni wspierały ustalenia Czirikowej. Dotyczyły one słabości centrum w relacjach z regionami, deficytu kadr zdolnych zarządzać regionami w imieniu centrum federalnego i zależności Kremla od zdolności gubernatorów do manipulowania zasobami administracyjnymi ${ }^{49}$. Jeśli już bowiem dochodziło w okresie drugiej kadencji prezydenckiej Putina do zmian na stanowiskach szefów regionów, to był to wynik konfliktu pomiędzy gubernatorem a wpływowym członkiem elity szczebla federalnego lub wyraźny kryzys społeczno-gospodarczy w regionie bądź $\mathrm{w}$ końcu chęć umieszczenia w regionie swojego człowieka przez którąś $\mathrm{z}$ wpływowych grup elit federalnych, mających posłuch u Putina ${ }^{50}$.

Regiony pozbawiono swojego przedstawicielstwa w Dumie Państwowej i w Radzie Federacji. Frakcja Jednej Rosji była spójna i zdyscyplinowana do tego stopnia, że skrajnie niepopularną ustawę o tzw. monetyzacji ulg socjalnych poparło w sierpniu 2004 r. 302 z 304 deputowanych „partii władzy”. Również w sierpniu tego samego roku podpisana została przez Putina ustawa wnosząca poprawki do kodeksu budżetowego, znacząco zmieniająca na korzyść centrum federalnego zasady dystrybucji podatków ${ }^{51}$. Tragedia w Biesłanie stała się natomiast doniosłym argumentem na rzecz dalszej centralizacji państwa, a obecność spójnej i dominującej w Dumie frakcji Jednej Rosji umożliwiła skuteczne działania legislacyjne w tym obszarze.

Odzyskaniem przez centrum federalne kontroli nad regionami zainteresowane było szerokie spektrum sił. Przyświecały im nierzadko odmienne intencje. Obrońcy praworządności i zwolennicy demokracji oczekiwali demontażu regionalnych reżimów autorytarnych i przywrócenia w Rosji jednolitej przestrzeni prawnej. Przedstawiciele wielkiego biznesu szczebla federalnego byli zainteresowani ekspansją regionalną, której przeciwstawiali się gubernatorzy i prezydenci republik narodowościowych. Centraliza-

48 Р.Ф. Туровский, Региональные выборы в России...

49 Ibidem.

50 Ibidem.

51 Рог. В.С. Милов, И.В. Яшин, Путин. Итоги. 2018. Независимый экспертный доклад, ИП Ермаков Д. Д., Москва 2018, s. 19; Федеральный закон „О внесении изменений в Бюджетньй кодекс Российской Федерации в части регулирования межбюджетных отночений” от 20.08.2004 2. No 120-Ф3, Администрация Президента России, http://www.kremlin.ru/acts/ bank/21330/page/1, inf. 14 VI 2018. 
cji sprzyjało również kierownictwo federalnych partii politycznych, którym wydatnie pomagał fakt likwidacji partii regionalnych. Regionalni sponsorzy zaczęli okazywać im zainteresowanie w obliczu nieuchronnie zbliżającego się momentu opuszczenia rynku wyborczego przez partie, które dotychczas gwarantowały im obecność w regionalnych zgromadzeniach ustawodawczych i lobbowanie swoich interesów ${ }^{52}$.

O defederalizacji Rosji przesądziły m.in. następujące wydarzenia i procesy: porażka Ojczyzny - Całej Rosji w wyborach do Dumy Państwowej w roku 1999 i spadek popularności Jewgienija Primakowa jako kandydata koalicji prezydencko-gubernatorskiej, pojawienie się na arenie politycznej Rosji młodego i energicznego premiera i p.o. prezydenta, którego reformatorska agenda obejmowała, obok odbudowy pozycji międzynarodowej Rosji, również jej wewnętrzną sanację, wymagającą centralizacji. Należy również zwrócić uwagę na brak koordynacji działań po stronie elit regionalnych w celu przeciwstawienia się poczynaniom centrum federalnego i ich kunktatorską postawę w chwili, kiedy dostrzegły korzyści wynikające z procesu centralizacji i możliwości adaptacji do nowych reguł gry. W późniejszym okresie centralizacji stosunków federacyjnych na elity polityczne regionów dyscyplinująco wpływały działania podejmowane przez resorty siłowe. Warto również $\mathrm{w}$ tym kontekście podkreślić zmianę nastrojów społecznych towarzyszących perspektywie centralizacji i płytkie zakorzenienie idei federalizmu w kulturze politycznej Rosjan, bez czego działania formalno-prawne byłyby zapewne trudniejsze do zrealizowania.

Centralizacja modelu rosyjskiego federalizmu miała wymiar formalny i nieformalny. Rozwiązania formalne były dopiero początkiem negocjacji pomiędzy Kremlem a elitami regionalnym na temat zasad ich implementacji - przyjęcie w roku 2004 ustawy znoszącej powszechne wybory szefów regionów nie pociągnęło za sobą automatycznych zmian w strukturze tego urzędu. Po roku 1999 w relacjach centrum-regiony $\mathrm{w}$ dalszym ciągu toczyły się negocjacje - $\mathrm{w}$ ujęciu procesualnym federalizm pozostał obecny w rosyjskim systemie politycznym. Jeśli przyjąć perspektywę neo-jarłyku, to przed rokiem 2000 negocjacje dotyczące suwerenności regionów były zjawiskiem powszechnym - czego przejawem okazała się duża liczba znaczących umów o rozgraniczeniu kompetencji i zakresów działania. Stroną dominującą w procesie negocjacji były regiony. Po tej dacie sytuacja uległa istotnej zmianie, centrum miało w rękach więcej atutów tak materialnych (wzrost dochodów do budżetu), jak i niematerialnych (afirmacja agendy sanacji państwa, akceptacja centralizacji państwa). W konsekwencji elity regionalne zaczęły zmieniać swój początkowo negatywny stosunek do działań Kremla, dostrzegając w nich nie tylko zagrożenie, lecz także korzyści. Miało to korzystny wpływ na stabilizację rosyjskiego autorytaryzmu. Jednak z punktu widzenia elit regionalnych, a w szczególności szefów regionów, przestrzeganie zasad porozumienia z Kremlem, tj. możliwość sprawowania niepodzielnej władzy na danym terytorium w zamian za gwa-

А. Кынев, „Обновленная” электоральная политика Кремля и регионы: старое новое и новое cтарое, „Неприкосновенный запас” 2015, nr 5 (103), Горький Медиа, http://magazines.russ. $\mathrm{ru} / \mathrm{nz} / 2015 / 103 / 5 \mathrm{k} \cdot \mathrm{html}$, inf. 14 VI 2018. 
rancję lojalności i utrzymywania porządku - zapewnienia stabilności i dostarczania zasobów, nie gwarantowało, że będzie on je honorował. Z drugiej zaś strony elity części regionów walczyły o swoją suwerenność i przeciwstawiały się woli centrum. W pewnych przypadkach szefowie regionów zaczęli podporządkowywać sobie struktury regionalne Jednej Rosji lub też stawała się ona areną konfliktów pomiędzy zwaśnionymi grupami elit.

\section{Federalizm jako „uśpiony" element rosyjskiego systemu politycznego}

Istnieje wiele prób interpretacji przyczyn i okoliczności demontażu federalizmu w Rosji po roku 2000 i zależności między typami reżimów politycznych Rosji epok Jelcyna i Putina a kształtującymi się przed i po roku 2000 modelami relacji centrum-regiony. Zdecydowanie mniej jest natomiast opracowań próbujących wytłumaczyć, dlaczego federalizm pozostaje „uśpioną” instytucją we współczesnej Rosji, tj. dlaczego Kreml nie zamierza rozstać się z federalistyczną „dekoracją" i wyeliminować federalizmu z grona konstytucyjnych podstaw ustroju rosyjskiego państwa. Jednym z rosyjskich politologów, który starał się wyjaśnić ten problem, był Andriej Zacharow ${ }^{53}$.

Przede wszystkim sugerował on, że federalizm wciąż formalnie pozostawał jedną z podstaw rosyjskiego ustroju politycznego, ponieważ nie szkodził. Kreml miał możliwość dokonywania dowolnych i rzeczywistych zmian w obrębie systemu stosunków federacyjnych, bez konieczności przeprowadzenia gruntownej i żmudnej rewizji konstytucji. Federalistyczne rozwiązania konstytucyjne nie powstrzymały centrum federalnego przed faktyczną centralizacją systemu politycznego i nie pobudziły szerokiej społecznej dyskusji nad zasadnością rewizji konstytucji ${ }^{54}$.

Kolejny argument był związany z kwestią rozchodzenia się litery prawa i praktyki politycznej we współczesnej Rosji. Konstytucja rosyjska nie pełniła „dyscyplinującej” funkcji, tak charakterystycznej dla państw demokracji liberalnej, rosyjska polityka i normy prawno-konstytucyjne miały funkcjonować, zdaniem Zacharowa, obok siebie, $\mathrm{w}$ dwóch równoległych rzeczywistościach. Zapisy federalistyczne zawarte w konstytucji były przy tym niejasne i w konsekwencji dwuznaczne. Otwierały szerokie możliwości interpretacji. Model konstytucyjny współistniał z traktatowym. Z jednej strony podkreślano w konstytucji równorzędny status podmiotów federacji, z drugiej mieliśmy do czynienia z dywersyfikacją ich formalno-prawnego statusu (republiki, obwody, okręgi autonomiczne, miasta o statusie federalnym). Rosyjski federalizm był wyrazem próby łączenia koncepcji terytorialnej (obwody) i etnoterytorialnej (republiki, okręgi autonomiczne). Zacharow, tłumacząc fakt zachowania federalizmu jako podstawy ustroju politycznego Rosji, wskazywał również, że miało to związek z heterogeniczną charakterystyką struktury społecznej współczesnej Rosji w wymiarze narodowościo-

\footnotetext{
А. Захаров, Российский федерализм как „спящий” институт, „Неприкосновенный запас” 2010, nr 3 (71), Горький Медиа, http://magazines.russ.ru/nz/2010/3/za12.html, inf. 9 VI 2018.

54 Idem, Унитарная федерация. Пять этюдов о российском федерализме, Московская школа политических исследований, Москва 2008, s. 114-116.
} 
wym. Obawy przed wzrostem napięcia etnopolitycznego blokowały dyskusje i tym samym działania na rzecz wykorzenienia elementu etnicznego z systemu stosunków federacyjnych i łączenia podmiotów federacji. Oznaczałoby to bowiem likwidację siedzib narodowych nierosyjskich mniejszości etnicznych, do których były one silnie przywiązane ${ }^{55}$. Kolejną kwestią sprzyjającą "podtrzymaniu federalizmu przy życiu” była rewizjonistyczna natura polityki zagranicznej Rosji Putina. Argument ten nabierał szczególnej aktualności z perspektywy roku 2014 i włączenia Krymu w skład Federacji Rosyjskiej. Odradzający się w Rosji duch mocarstwowości, zdaniem Zacharowa, mógł być skutecznie wykorzystany w celu legitymacji reżimu politycznego, Kreml potrzebował triumfu w sferze polityki międzynarodowej, np. w postaci ekspansji terytorialnej i niezbędnych narzędzi jej realizacji. Takim narzędziem mógł być federalizm, jako że według Rikera - pozostawał on jedynym rozwiązaniem pozwalającym na zdobywanie nowych terytoriów- bez konieczności uciekania się do użycia siły. Nowi członkowie dołączający do federacji (rebelianci uciekający przed dominacją imperium) czują się bardziej komfortowo niż w przypadku dołączania do państw unitarnych, gdyż mają poczucie, że ich odrębność będzie w jakimś stopniu poszanowana i prawnie zagwarantowana $^{56}$. Federacje $\mathrm{z}$ samej swej natury gwarantują bowiem podmiotom składowym daleko idącą autonomię i możliwość wpływania na politykę rządu federalnego.

Ostatnim argumentem przemawiającym na rzecz zachowania federalizmu była tzw. federalistyczna (lub raczej pseudo-federalistyczna) współodpowiedzialność regionów za rządzenie państwem. Ten kluczowy z punktu widzenia rozważań nad miejscem i rolą federalizmu we współczesnej Rosji argument Zacharowa zasadzał się na założeniu, że mimo koncentracji pełni władzy w obrębie jednego ośrodka decyzyjnego, konsekwentnego „odzierania” regionów z pełnomocnictw w ramach niezrozumiałego dla większości obywateli procesu ich rozgraniczenia Kreml nie odżegnywał się od retoryki federalistycznej, aby uniknąć pełnej odpowiedzialności za ewentualne potknięcia i porażki w procesie zarządzania państwem. Kiedy dochodziło do spektakularnego niepowodzenia, np. podczas realizacji któregoś z „projektów narodowych”, można było przerzucić odpowiedzialność (lub chociaż jej część) na regionalne organy władzy, które w ramach swoich kompetencji nie poradziły sobie z zadaniem. Centrum federalne samodzielnie kształtuje strategiczny kurs rozwoju państwa, rozdziela zasoby i rozgranicza pełnomocnictwa, zachowując się jak rząd państwa unitarnego, kiedy zaś należy ponosić odpowiedzialność, zrzuca ją na regiony ${ }^{57}$.

55 Д. Камышев, Зона странного электорального поведения, „Коммерсантъ Власть” 17.12.2007, s. 32; Д.Б. Орешкин, Д.Д. Орешкина, География электоральной культуры России, „Общественные науки и современность” 2006, nr 5, s. 20-34.

56 Por. W.E. Riker, op. cit., s. 8-9.

57 А. Захаров, Унитарная федерация..., s. 124-125. 


\section{Podsumowanie}

Podsumowując, w ciągu lat 2000-2016 Kreml włożył sporo wysiłku, by zweryfikować federalistyczne dziedzictwo Borysa Jelcyna. Regiony pozbawiano wpływu na proces decyzyjny na szczeblu federalnym, ustanowiono ścisłą kontrolę nad najwyższymi osobami urzędowymi podmiotów, zlikwidowano część elementów konstrukcji „zdecentralizowanego i asymetrycznego federalizmu” - nie rozwiązując głębokich dysproporcji pomiędzy rozwojem społeczno-gospodarczym regionów, a w końcu dokonano ustawowego rozgraniczenia konstytucyjnych kompetencji centrum i regionów, przekształcając te ostatnie w „agendy rządu federalnego”. Centrum zwiększyło zakres obowiązków regionów, jednocześnie zmniejszając ich bazę finansową i wysyłając na prowincję coraz większą liczbę urzędników federalnych, co - zdaniem przedstawicieli organów władzy państwowej podmiotów składowych Rosji - „nie odzwierciedlało realnych proporcji w rozgraniczeniu pełnomocnictw pomiędzy federacją a regionami”"58.

Całość procesu reformy stosunków federacyjnych dokonywała się z pominięciem debaty publicznej i udziału w niej społeczeństwa, w warunkach poddawania elit regionalnych presji psychologicznej mającej skłonić je do współpracy. Koncentracji władzy przez centrum federalne towarzyszyło zachłanne gromadzenie kompetencji i zasobów finansowych. W wymiarze politycznym centralizacja stosunków federacyjnych w Rosji Putina zbiegała się z postępującą konsolidacją reżimu autorytarnego.

Dywersyfikacja społeczno-gospodarcza, polityczna i etniczna regionów pozostała cechą szczególną rosyjskiego federalizmu, który w pełni zasługiwał na miano asymetrycznego ${ }^{59}$. Jednocześnie ze względu na konsekwentne akcentowanie przez obóz władzy pozytywnej roli federalizmu we współczesnej Rosji i brak gotowości Kremla do wyeliminowania z tekstu konstytucji zapisów federalistycznych, w połączeniu z „wypłukiwaniem" federalistycznej treści ze stosunków centrum-regiony przyjmuje się określać Rosję „federacją bez federalizmu”. Jeśli natomiast wziąć pod uwagę fakt, że Kreml próbuje „pogodzić” dobrodziejstwa federalizmu z praktyką państwa unitarnego, federalizmowi we współczesnej Rosji przypisuje się termin „unitarny”"60.

Jeśli chodzi o federalistyczny układ antynomiczny W.E. Rikera, rosyjski model federalizmu wyraźnie zbliżył się w wyniku działań Kremla w stronę bieguna maksymalnego. Odnosząc się do płaszczyzny analizy rosyjskiego systemu stosunków federacyjnych konstruowanej wokół osi modelu „patrol policyjny” $v s$ „alarm przeciwpożarowy”, można przyjąć, że w omawianym okresie zdecydowanie zbliżył się do modelu „patrolu policyjnego".

\footnotetext{
И. Голубицкая, ор. cit.

59 Г. Неяскин, Шесть карт, которые объясняют Россию, Slon Magazine, 30.10.2015, https://slon. ru/posts/58717, inf. z 9 VI 2018.

60 А. Захаров, Унитарная федерация..., s. 114-116.
} 
Pobrane z czasopisma Wschód Europy http://journals.umcs.pl/we

Data: 26/04/2023 15:16:17

Współczesny model rosyjskiego federalizmu: dynamika zmian, przesłanki i konsekwencje

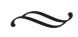

Streszczenie: Celem pracy jest osadzenie rosyjskiego modelu federalizmu (przemian dokonujących się w układzie Centrum-regiony) we współczesnej siatce teoretyczno-pojęciowej federalizmu, za pomocą analizy przemian dokonujących się w latach 2000-2016 w obrębie systemu stosunków federacyjnych w Rosji.

Autor stosuje metodę historyczną, egzegezę aktów prawnych i metodę ideacyjną. Szczególnie interesująca, zdaniem autora, jest próba odniesienia rosyjskiego modelu stosunków federacyjnych do osi typów idealnych federalizmu autorstwa W. H. Rikera i koncepcji modelu "patrolu policyjnego" i „alarmu przeciwpożarowego".

Autor stara się odpowiedzieć na następujące: 1. Jak przebiegała ewolucja stosunków federacyjnych w Rosji po roku 1999?; 2. Co charakteryzuje instytucjonalizację systemu mechanizmu monitoringu działań organów władzy państwowej szczebla regionalnego?; 3. Jak wyglądała ewolucja nowego formatu relacji Kreml-elity regionalne i czy była ona utrzymana w duchu modelu neojarłyku?; 4. Jakie były przesłanki zmian w obrębie systemu stosunków federacyjnych i ich konsekwencje? Odpowiedź na te pytania pozwoli zweryfikować trzy hipotezy:

H1. Ze względu na brak gotowości Kremla do wyeliminowania z tekstu konstytucji zapisów federalistycznych, w połączeniu z "wypłukiwaniem” federalistycznej treści ze stosunków centrum-regiony, przyjmuje się określać Rosję "federacją bez federalizmu”. Próby "pogodzenia” dobrodziejstwa federalizmu z praktyką państwa unitarnego pozwalają zdefiniować federalizm współczesnej Rosji jako „unitarny".

H2. Rosyjski model federalizmu wyraźnie zbliżył się w wyniku działań Kremla po roku 1999 w stronę bieguna maksymalnego.

H3. Odnosząc się do płaszczyzny analizy rosyjskiego systemu stosunków federacyjnych konstruowanej wokół osi modelu „patrol policyjny” vs. „alarm przeciwpożarowy”, można przyjąć, że w omawianym okresie zdecydowanie zbliżł się on do modelu „patrolu policyjnego".

Słowa kluczowe: Rosja, federalizm, stosunki federacyjne, Władimir Putin.

\section{Современная модель российского федерализма: динамика изменений, предпосылки и последствия}

Аннотация: Целью данной работы является включение российской модели федерализма (изменения, происходящие в системе Центр - регионы) в современную теоретическую и концептуальную сетку федерализма с использованием анализа изменений, произошедших в 2000 - 2016 гг. в системе федеративных отношений в России. В сщоич исследованиях Автор использует исторический метод, толкование правовых актов и идейный метод. Особенно интересной, по мнению автора, является попытка соотнести российскую модель федеративных отношений с идеальными типами федерализма У. Х. Райкера и концепциями моделей «полицейский патруль» и «пожарная сигнализация». Автор пытается ответить на следующие вопросы: 1. Как развивалась федеративные отношения в России после 1999 г.? 2. Что характеризует институционализация системы механизма мониторинга деятельности региональных органов госу- 
дарственной власти? 3. Какова была эволюция нового формата отношений между Кремлем и региональными элитами, и поддерживалась ли она в духе модели неоярлык? 4. Каковы были предпосылки для изменений в федеративной системе отношений и их последствия. Ответ на эти вопросы подтвердит три гипотезы: Г1. Кремль не готов исключить федеративные положения из конституции, поэтому в сочетании с «вымыванием» федералистского содержания из отношений центр - регионы, принято называть Россию «федерацией без федерализма». Попытки «примирить» преимущества федерализма с практикой унитарного государства позволяют определить федерализм современной России как «унитарный». Г2. В результате действий Кремля после 1999 года российская федеральная модель явно приблизилась к максимальному полюсу. НЗ. Обращаясь к плоскости анализа российской системы федеративных отношений, построенной вокруг оси модели «полицейский патруль» против «пожарная тревога», можно предположить, что в обсуждаемый период она однозначно приблизилась к модели «полицейского патруля».

Ключевые слова: Россия, федерализм, федеративные отношения, Владимир Путин.

\section{Contemporary model of Russian federalism: dynamics of changes, premises and consequences}

Abstract: The aim of the work is to embed the Russian model of federalism (changes taking place in the Center - regions system) in the modern theoretical and conceptual grid of federalism, using the analysis of changes taking place in $2000-2016$ within the system of federal relations in Russia. The author uses the historical method, exegesis of legal acts and ideational method. Particularly interesting, according to the author, is the attempt to relate the Russian model of federal relations to the ideal types of federalism by W. H. Riker and the concept of the model of "police patrol" and "fire alarm". The author tries to answer the following: 1. How was the evolution of federal relations in Russia after 1999? 2. What characterizes the institutionalization of the system of the mechanism of monitoring the activities of regional state authorities? 3 . What was the evolution of the new format of relations between the Kremlin and the regional elites, and was it maintained in the spirit of the neo-warrior model? 4 . What were the premises for changes within the federal relations system and their consequences. Answering these questions will verify three hypotheses: $\mathrm{H} 1$. Due to the Kremlin's lack of readiness to eliminate federalist provisions from the constitution, in conjunction with the "leaching" of federalist content from the center-regions relations, it is accepted to call Russia "a federation without federalism." Attempts to "reconcile" the benefits of federalism with the practice of a unitary state allow defining the federalism of modern Russia as "unitary". H2. As a result of the Kremlin's actions after 1999, the Russian federal model has clearly approached the maximum pole. H3. Referring to the plane of analysis of the Russian system of federal relations constructed around the axis of the model "police patrol" vs. "fire alarm", it can be assumed that in the discussed period it definitely came close to the model of "police patrol".

Keywords: Russia, federalism, federal relations, Vladimir Putin. 
Pobrane z czasopisma Wschód Europy http://journals.umcs.pl/we

Data: 26/04/2023 15:16:17

Współczesny model rosyjskiego federalizmu: dynamika zmian, przesłanki i konsekwencje

\section{Bibliografia}

Boos nie ostanietsia gubiernatorom Kaliningradskoj obłasti, Rusbase, https://rb.ru/article/boos-neostanetsya-gubernatorom-kaliningradskoy-oblasti/6510297.html, inf. 6 VI 2018.

Boris Jelcyn: „Bieritie stolko suwierinietieta, skolkosmożetie progłotit", 06.07.2015, Priezidientskij Centr

B. N. Jelcyna, https://yeltsin.ru/news/boris-elcin-berite-stolko-suverineteta-skolko-smozheteproglotit/, inf. $16 \mathrm{VI} 2018$.

Busygina I., Russian Federalism, [w:] Russia Strategy, Policy and Administration, red. I. Studin, Palgrave Macmillan, UK, Basingstoke 2018, s. 57-64.

Czirikowa A. Je., Institut Socyołogiirossijskoj akadiemii nauk, Mieżdunarodnyj fond socyalno-ekonomiczeskich ipolitołogiczeskich issledowanij, http://www.gorby.ru/userfiles/chirikova(1).pdf, inf. 9 VIII 2018.

Czirikowa A. Je., Putinskije rieformy i pozicyonirowanije riegionalnych elit w Rossii, „Mir Rossii. Socyołogija. Etnołogija" 2006, nr 15 (1), s. 3-27.

Czirikowa A. Je., Wiertikal własti wocenkach riegionalnych elit: dinamika pieriemien, „Polis. Politiczeskijeissledowanija" 2008, nr 6, s. 99-112.

Fiedieralnyj zakon „0 wniesienii izmienienij w biudżetnyj kodieks Rossijskoj Fiedieracyi w czasti riegulirowanija mieżbiudżetnych otnoszenij" ot 20.08.2004 g. No120-FZ, Administracyja Priezidienta Rossii, http://www.kremlin.ru/acts/bank/21330/page/1, inf. 14 VI 2018.

Fiedieratiwnyjdogowor (Moskwa, 37 marta 1992 g.), NPP "Garant-Sierwis", http://constitution.garant.ru/ act/federative/170280/, inf. 16 VI 2018.

Gołubicka I., Za 15 let czisło czinownikow w Rossii wyrosło wdwoje, 16.01.2017, Myslo.ru, https://myslo. ru/news/tula/2017-01-16-za-15-let-chislo-chinovnikov-v-Rossii-viroslo-vdvoe, inf. z $16 \mathrm{VI} 2018$.

Knowoj modieli rossijskogofiedieralizma: wzglad iz riegionow. Dokłady projekta - 2012, Gorbaczew-fond, Moskwa 2012.

Kahn J., Russia: Federalism, Democratization, Rule of Law, Oxford University Press, Oxford 2002.

Kamyszew D., Zona strannogo elektoralnogo powiedienija, „Kommiersant Włast" 17.12.2007.

Korczenkowa N., Wsia włast subjektam. Kak w Rossii mienialis fiedieratiwnyje otnoszenija - w spiecyalnom projektie "D”, „Kommiersant” 31.03.2018, Kommiersant, https://www.kommersant.ru/ doc/3585452, inf. $11 \times 2018$.

Kyniew A., „Obnowlennaja” elektoralnaja politika Kriemla i riegiony: staroje nowoje i nowojestaroje, ,Nieprikosnowiennyj Zapas" 2015, nr 5 (103), Gor kij Miedia, http://magazines.russ.ru/nz/2015/103/5k. html, inf. 14 VI 2018.

Markies I., Nazrułtajewa Je. Ju., Jakowlew A.A., Dien gi wmiesto rosta: mieżbiudżetnyje transfierty i elektoralnaja poddierżka w Rossii, 2001-2008, Izd. dom Wysszej szkoły ekonomiki, Moskwa 2013.

Miłow W.S., Jaszyn I. W., Putin. Itogi. 2018. Niezawisimyj ekspiertnyj dokład, IP Jermakow D. D., Moskwa 2018.

Niejaskin G., Szest kart, kotoryje objasniajut Rossiju, Slon Magazine, 30.10.2015, https://slon.ru/ posts/58717, inf. z 9 VI 2018.

Nożenko M.W., Starodubcew A.W., Odna naucznaja zagadka, ili Poczemu gubiernatory sogłasilis spriezidientom, [w:] Fiedieralizm i rossijskije riegiony: sbornik statiej, INION RAN, Moskwa 2006.

Orieszkin D.B., Orieszkina D.D., Gieografijaelektoralnoj kultury Rossii, „Obszczestwiennyje nauki i sowriemiennost" 2006, nr 5, s. 20-34. 
Piercew A., Samochina S., Siniergijew I., Riegionalnyje pieriemiennyje. Czego choczet Moskwa ot nowych gubiernator, „Kommiersant Włast" 11.02. 2017.

Pietrow N., Rogow K., Ispołnitielnaja włast i siłowyje korporacyi, [w:] Politiczeskoje razwitije Rossii. 2014-2016: Instituty i praktiki awtoritarnoj konsolidacyi, red. A.W. Kyniew, A.G. Kaczkajewa, E.t. Paniejach, Fond Libieralnajamissija, Moskwa 2016, s. 133-153.

Politiczeskoje razwitije Rossii. 2014-2016: Instituty i praktiki awtoritarnoj konsolidacyi, red. A.W. Kyniew, A.G. Kaczkajewa, E.Ł. Paniejach, Fond Libieralnajamissija, Moskwa 2016.

Reuter 0. J., The Politics of Cooptation. United Russia and Russia's Governors, s. 4, American Councils for International Education, http://researchfellowships.americancouncils.org/sites/researchfellowships.americancouncils.org/files/Reuter_final_report.pdf, inf. 4 IV 2017.

Riejting wlijanija gławsubjektow Rossijskoj Fiedieracyi w nojabrie 2016 g., 06 XII 2016, http://www. apecom.ru/articles/?ELEMENT_ID=3262, inf. 6 IV 2017.

Riker W.E., The Development of American Federalism, Kluwer Academic Publisher, Boston 1987.

Ross C., Turovsky R., Centralized but Fragmented: The Regional Dimension of "Russia's Party of Power", „Demokratizatsiya” 2015, vol. 23, nr 2, s. 205-223.

Russia Strategy, Policy and Administration, red. I. Studin, Palgrave Macmillan, UK, Basingstoke 2018.

Russia's Far East, red. J. Thornton, C. E. Ziegler, National Bureau of Asian Research, Seattle-London 2002.

Samochina S., Krieml razrabotał kritierii effiektiwnosti dla gubiernatorow, Lenta nowostiej (Moskwa) ot 17.02.2017, 16:14, Kommiersant, http://www.kommersant.ru/doc/3223648, inf. 18 || 2017.

Schedler A., The New Institutionalism in the Study of Authoritarian Regimes, "Totalitarismus und Demokratie" 2009, nr 6, s. 36-50. D0l: https://doi.org/10.13109/tode.2009.6.2.323.

Sharafutdinova G., Gestalt Switch in Russian Federalism: The Decline in Regional Power under Putin, „Comparative Politics” 2009, vol. 45, nr 3, s. 357-376.

Starodubcew A., Biespoleznojedostiżenije? Gubiernatorskije wybory w kontiekstie problem riegionalnogo razwitija, "Nieprikosnowiennyj zapas” 2012, nr 4 (84), Gor kij Miedia, http://magazines.russ.ru/ nz/2012/4/s8.html, inf. 14 VI 2018.

Starodubrowskaja I., Głazyczew W., Fiedieralizm istinnyj i mnimyj, Statja jawlajetsia fragmientom dokłada "Stratiegija-2020: Nowaja modiel rosta - nowaja socyalnaja politika”, podgotowlennogo gruppoj rossijskich ekspiertow, „Moskowskije Nowosti”, 14 IX 2011, Moskowskije nowosti, https://www.hse.ru/ data/2013/10/30/1283340742/\%D0\%A1\%D1\%82\%D1\%80\%D0\%B0\%D1\%82\%D0\%B5\%D0\%B3\%D0 \%B8\%D1\%8F-2020_\%D0\%9A\%D0\%BD\%D0\%B8\%D0\%B3\%D0\%B0\%201.pdf, inf. 11 X 2018.

Starodubtsev A., Bureaucratic Strength and Presidential Inattention: Disempowering Territorial Development Instruments in Russia, „Russian Analytical Digest” 18 IV 2017, nr 201, s. 10-12, Russian Analytical Digest, http://www.css.ethz.ch/content/dam/ethz/special-interest/gess/cis/center-for-securities-studies/pdfs/RAD201.pdf, inf. 8 IX 2018, s. 10-13.

Starodubtsev A., Decentralizebutnot Federalize: The Authoritarian Pattern of Regional Policy Report for ECPR General Conference 2013, 4-7 September, 2013, ECPRGeneralConference, https://ecpr.eu /.../239166c3-0dd8-456b-a58f-1e0f6de73ed2.pdf, inf. 9 VI 2018.

Stepan A., Toward a New Comparative Analysis of Democracy and Federalism: Demos Constraining and Demos Enabling Federations, Paper presented at the conference on Federalism, Democracy, and Public Policy Centro de Investigación y Docencia Económicas, Mexico City, Mexico June 14-15, 1999. 
Pobrane z czasopisma Wschód Europy http://journals.umcs.pl/we

Data: 26/04/2023 15:16:17

Współczesny model rosyjskiego federalizmu: dynamika zmian, przesłanki i konsekwencje

Stepan A., Federalism and Democracy: Beyond the U.S. Model, „Journal of Democracy” 1999, vol. 10, nr 4, s. 19-34. DOl: https://doi.org/10.1353/jod.1999.0072.

Stoner-Weiss K., Resisting the State: Reform and Retrenchment in Post-Soviet Russia, Cambridge University Press, Cambridge 2006.

The Politics of Sub-National Authoritarianism in Russia, red. C. Ross., V. Gel'man, Routledge, Ashgate, Aldershot 2010.

Tsebelis G., Veto Players: How Political Institutions Work, Princeton University Press, Princeton New York 2011.

Volden C., The Federalism of William H. Riker Origin, Operation, and Significance, „Publius: The Journal of Federalism" 2004, vol. 34, nr 4, s. 89-107.

Zacharow A., Rossijskij fiedieralizm kak "spiaszczij” institut, „Nieprikosnowiennyj zapas”, 2010, nr 3 (71), Gor kij Miedia, http://magazines.russ.ru/nz/2010/3/za12.html, inf. z 9 VI 2018.

Zacharow A., Unitarnaja fiedieracyja. Piat etiudow o rossijskom fiedieralizmie, Moskowskaja szkoła politiczeskich issledowanij, Moskwa 2008.

Zaporożan A. Ja., Problemy i tiendiencyi razwitija mieżbiudżetnych otnoszenij w Rossii, „Uprawlenczeskoje Konsultirowanije" 2015, nr 4, s. 70-79.

Zubarewich N., Four Russias: the New Political Reality, "Open Democracy”, 1 || 2016, Open Democracy, https://www.opendemocracy.net/od-russia/natalia-zubarevich/four-russias-new-political-reality, inf. z 6 IV 2017.

Zubariewicz N., Briemia riegionow": czto izmieniłos za diesiat let?, „Kontrapunkt” 2016, nr 6, s. 1-9.

Zubariewicz N., Gieopoliticzeskije prioritiety w riegionalnoj politikie Rossii: wozmożnosti i riski, „Kontrapunkt" IX 2015, nr 1, s. 1-11. 